\title{
Uncovering China's greenhouse gas emission from regional and sectoral perspectives
}

\author{
Zhu Liu $^{\mathrm{a}, \mathrm{b}}$, Yong Geng ${ }^{\mathrm{a}, *}$, Soeren Lindner ${ }^{\mathrm{a}, \mathrm{c}}$, Dabo Guan ${ }^{\mathrm{a}, \mathrm{d}}$ \\ a Key Laboratory of Pollution Ecology and Environmental Engineering, Institute of Applied Ecology, Chinese Academy of Sciences, Shenyang, China \\ ${ }^{\mathrm{b}}$ Graduate School of Chinese Academy of Sciences, Beijing, China \\ ${ }^{\mathrm{c}}$ Cambridge Centre for Climate Change Mitigation Research, Department of Land Economy, University of Cambridge, United Kingdom \\ d School of Earth and Environment, University of Leeds, United Kingdom
}

\section{A R T I C L E I N F O}

\section{Article history:}

Received 9 January 2012

Received in revised form

20 May 2012

Accepted 4 June 2012

Available online 20 July 2012

\section{Keywords:}

China's province

GHG emission

Coefficient of variation

Index decomposition analysis

Driving forces

\begin{abstract}
A B S T R A C T
Understanding China's GHG (greenhouse gas) emission status is critical for achieving the national mitigation plan. While much attention has addressed China's national level GHG emission, less is known about its regional and sectoral emission features. In this paper China's regional and sectoral GHG emission patterns and their driving forces were explored by using upgraded energy consumption data. We constructed a detailed GHG inventory for each province in the year 2009 which covering 28 sectors and further expanded time-serious inventories during 1997-2009. We then conducted variation and index decomposition analysis to explore its sectoral/regional disparity and features. Results showed significant differences of sectoral emission intensity among different provinces, implying a huge disparity of technology level. Since less developed provinces still apply energy intensive technologies, they had contributed to most of national emission increment during 1997-2009 and made the whole country towards carbon intensive direction. Our research outcomes indicate that the inequity of technology level among regions has already become a main barrier for China's $\mathrm{CO}_{2}$ mitigation. Such a reality deserves more attention from both researchers and policy makers so that appropriate carbon reduction policies can be raised.
\end{abstract}

(c) 2012 Elsevier Ltd. All rights reserved.

\section{Introduction}

As the world's largest primary energy consumer and GHG (green house gas) emitter, China was responsible for $25 \%$ of global energy resource consumption and 20\% of global GHG emissions in 2009 $[1,2]$. Under such a circumstance, China's mitigation action is crucial for both domestic sustainable development and the world's efforts on Green house Gas (GHG) control. Multiple efforts have been made from both institutional and individual perspectives. The National Leading Committee on Climate Change (NLCCC) was established in 2007, aiming to develop China's National Climate Change Program, set up objectives, make action plans for reducing energy consumption and adapting to climate change [3]. In 2009 national government committed to a voluntary reduction of GHG emissions, namely, to reduce the intensity of carbon dioxide emissions per unit of GDP in 2020 by $40-45$ percent compared with the level of 2005 [4]. Since then several concrete policies

\footnotetext{
* Corresponding author. Circular Economy and Industrial Ecology Research Group, Institute of Applied Ecology, Chinese Academy of Science, Shenyang Liaoning Province 110016, PR China. Tel.: +86 24 83970372; fax: +86 2483970371.

E-mail address: gengyong@iae.ac.cn (Y. Geng).
}

have been enacted, including a restriction on establishing new fossil fuel power plants, increasing the use of renewable energy sources in the power sector, releasing provincial energy intensity reduction targets, as well as the phase-out of inefficient coalburning power plants with less than $100 \mathrm{MW}$ capacity [5]. In practice, such policies are implemented in combination with the National Economic and Social Development Plan, which advocates regional "low carbon" development projects [6].

However, due to an insufficient understanding of China's emission status at the regional and sector level, such policies cannot be effectively and efficiently implemented. On the one hand, owing to China's large size and imbalanced development, the lifestyle, resource endowment and economic development perspectives in different provinces are significantly different. While more developed eastern coastal regions have highly improved their regional economy, some of the less developed western regions are still struggling to meet basic life demands, and are now under heavy environmental pressures [7]. For instance, several provinces have selected to support the development of heavy industries due to their rich natural resources [8]. But without a holistic consideration on environmental protection and resource efficiency, these provinces are now facing resource depletion and various 
environmental challenges. Meanwhile, such provinces do not have adequate human resources to upgrade their technologies and equipment and mainly rely on energy intensive industries for pushing their economy, leading to inefficient resource use and a great amount of GHG emissions. Typical provinces include Heilongjiang, Shanxi, Xinjiang, Inner Mongolia and Qinghai [9]. As a result, those developing regions have discharged higher overall $\mathrm{CO}_{2}$ emissions [10].

On the other hand, current top-down energy saving and emission reduction approaches do not sufficiently consider regional disparity and actual drivers. For instance, the recently published 12th Five-Year Plan for Social and Economic Development addressed energy intensity reduction targets for each province. However, although the magnitude of differences on energy intensity between highest and lowest regions is as high as $500 \%$, the disparity of energy intensity reduction target is only up to $50 \%$ [11] (Table 1).

Moreover, technology transfer required from developing countries aroused pressing concern in international climate negotiation [12]. But such industrial technology differences are not just between North and South or amongst developing countries, but also within one country such as China. While significant technology differences exist among different states of US [13], the technology differences of certain industries among Chinese provinces are much larger. For example, the energy use of electricity production in Yunnan province of the southwest China in 2010 is twice than that of Guangdong on the south coast [11], such differences are even larger for cement and metal processing industries.

Thus, it is critical to undertake a comprehensive study, not only considering the spatial distribution of $\mathrm{CO}_{2}$ emissions, but also quantitatively focusing on the variation of emission status from

Table 1

China's energy intensity targets and achievements.

\begin{tabular}{|c|c|c|c|c|}
\hline Province & $\begin{array}{l}\text { Energy } \\
\text { intensity } \\
\text { goal } \\
(2005-2010)\end{array}$ & $\begin{array}{l}\text { Energy } \\
\text { intensity } \\
\text { goal } \\
\text { achievement } \\
(2005-2010)\end{array}$ & $\begin{array}{l}\text { Energy } \\
\text { intensity } \\
\text { in } 2010 \\
\text { (ton } / 10^{4} \mathrm{RMB} \text { ) }\end{array}$ & $\begin{array}{l}\text { Energy } \\
\text { intensity } \\
\text { goal }(2010 \\
-2015)\end{array}$ \\
\hline Beijing & $-20 \%$ & $-26.59 \%$ & 0.582 & $17 \%$ \\
\hline Tianjin & $-20 \%$ & $-21.00 \%$ & 0.826 & $18 \%$ \\
\hline Hebei & $-20 \%$ & $-20.11 \%$ & 1.583 & $17 \%$ \\
\hline Shanxi & $-22 \%$ & $-20.66 \%$ & 2.235 & $16 \%$ \\
\hline $\begin{array}{l}\text { Inner } \\
\text { Mongolia }\end{array}$ & $-22 \%$ & $-22.62 \%$ & 1.915 & $15 \%$ \\
\hline Liaoning & $-20 \%$ & $-20.01 \%$ & 1.38 & $17 \%$ \\
\hline Jilin & $-22 \%$ & $-22.04 \%$ & 1.145 & $16 \%$ \\
\hline Heilongjiang & $-20 \%$ & $-20.79 \%$ & 1.156 & $16 \%$ \\
\hline Shanghai & $-20 \%$ & $-20.00 \%$ & 0.712 & $18 \%$ \\
\hline Jiangsu & $-20 \%$ & $-20.45 \%$ & 0.734 & $18 \%$ \\
\hline Zhejiang & $-20 \%$ & $-20.01 \%$ & 0.717 & $18 \%$ \\
\hline Anhui & $-20 \%$ & $-20.36 \%$ & 0.969 & $16 \%$ \\
\hline Fujian & $-16 \%$ & $-16.45 \%$ & 0.783 & $16 \%$ \\
\hline Jiangxi & $-20 \%$ & $-20.04 \%$ & 0.845 & $16 \%$ \\
\hline Shandong & $-22 \%$ & $-22.09 \%$ & 1.025 & $17 \%$ \\
\hline Henan & $-20 \%$ & $-20.12 \%$ & 1.115 & $16 \%$ \\
\hline Hubei & $-20 \%$ & $-21.67 \%$ & 1.183 & $16 \%$ \\
\hline Hunan & $-20 \%$ & $-20.43 \%$ & 1.17 & $16 \%$ \\
\hline Guangdong & $-16 \%$ & $-16.42 \%$ & 0.664 & $18 \%$ \\
\hline Guangxi & $-15 \%$ & $-15.22 \%$ & 1.036 & $15 \%$ \\
\hline Hainan & $-12 \%$ & $-12.14 \%$ & 0.808 & $10 \%$ \\
\hline Chongqing & $-20 \%$ & $-20.95 \%$ & 1.127 & $16 \%$ \\
\hline Sichuan & $-20 \%$ & $-20.31 \%$ & 1.275 & $16 \%$ \\
\hline Guizhou & $-20 \%$ & $-20.06 \%$ & 2.248 & $15 \%$ \\
\hline Yunnan & $-17 \%$ & $-17.41 \%$ & 1.438 & $15 \%$ \\
\hline Tibet & $-12 \%$ & $-12.00 \%$ & 1.276 & $10 \%$ \\
\hline Shannxi & $-20 \%$ & $-20.25 \%$ & 1.129 & $16 \%$ \\
\hline Gansu & $-20 \%$ & $-20.26 \%$ & 1.801 & $15 \%$ \\
\hline Qinghai & $-17 \%$ & $-17.04 \%$ & 2.55 & $10 \%$ \\
\hline Ningxia & $-20 \%$ & $-20.09 \%$ & 3.308 & $15 \%$ \\
\hline
\end{tabular}

Source: National Development and Reform Commission (NDRC) $[8,9]$. industry sectors. This requires a "bottom-up" analysis of China's provincial and sectoral $\mathrm{CO}_{2}$ emission.

This study fills such a gap by constructing a "bottom-up" inventory of GHG emissions, covering 28 economic sectors from 30 provinces in 2009 and expanding time-series for the period of 1997-2009. In order to quantify disparities on regional/sectoral emission status, a Coefficient of Variation (CV) is applied. Moreover, a logarithmic mean divisa Index (LMDI) model is employed to uncover how different sectors can contribute to GHG emissions in different provinces and national total as well, so that rational policy implications can be presented.

\section{Methodology}

\subsection{Literature review}

The unprecedented economic growth has driven China to be the world top $\mathrm{CO}_{2}$ energy consumer and emitter. This reality received a lot of attention from both academic and public perspectives, addressing the features of China's $\mathrm{CO}_{2}$ emission [14,15], regional distribution, relationship with international trade [16] and the driving forces for historical change [17,18]. Research outcomes presented a huge disparity of emission status among Chinese regions. For example, Liang et al. [19] highlighted the disparity of energy efficiency among China's eight main economic regions. Liu et al. [20] revealed that China's total emission increment during 1997-2007 were mainly caused by several industrial development provinces. Meng et al. [21] found a huge disparity among different provinces and significant $\mathrm{CO}_{2}$ emission transfer through crossregional electricity supply. Afton et al. [22] underlined the interand inner regional equity issue, and similar insights were also offered by Wei et al. [23].

These pioneer studies recognized regional disparity and built up a solid foundation for comprehensive understanding on China's regional GHG emission status. However, it has not been studied on how technology level differences among different regions influenced provincial emissions. Such disparity has a direct effect on regional development and related energy saving and mitigation policies and should be further studied. Recently, numerous studies focused on detailed sector classification of China's regional GHG emissions and shed light on emissions from industrial sectors. For example, Liu, et al. [24] analyzed the sector emission pattern in China's four mega cities. Liang and Zhang used an input-output model to analyze sector driver of emission change in Jiangsu province. Bi et al. [25] built a bottom-up sector emission inventory in Nanjin, and another city case in Shenyang was conducted by Xi et al. [26]. However, a panel analysis which includes a detailed industrial classification and also covers all the provinces has yet been conducted. The reason is mainly due to difficulties on data collection for sector energy use and construction of related emission inventories for all the 30 provinces. While panel analysis at provincial level can be explored by using "top-down" emission inventories based on national energy use statistical data, the sectoral/regional integrated analysis requires "bottom-up" emission inventories. However, sectoral detailed energy use data were not available in pervious national energy statistics.

In order to fill such a gap, in this paper we constructed a "bottom-up" emission inventory for China's 30 provinces by using a new data set. In the end of 2008 the National Bureau of Statistics (NBS) undertook a national investigation to check the detailed industrial energy use for all the provinces. Released in the Chinese Economic Census Yearbook (CECY) and published in 2011 [27], CECY shows energy use for 39 industrial sectors in 2008. Our "bottom-up" emission inventory in this paper is based on energy use data from CECY, and in consistence with the IPCC sectoral 
approach and the accounting process proposed by Peters [28], Fridley [29] and our previous case in Shenyang [26]. The provincial inventories covers 30 provinces and contains detailed energy use data from 28 industrial sectors in 2008 and 2009 (Emissions in 2009 were calculated based on the method proposed by Peters [30]). We further explore provincial time-series inventory, including 5 groups (Agriculture, Manufacturing, Construction, Commercial Industry and Transportation) during 1997-2009. Such an approach can facilitate us to perform an integrated analysis both from sectoral and regional perspectives.

\subsection{Data sources and GHG inventory}

Data for this study comes from various sources. The Chinese Energy Statistics Yearbooks (CESY) [11], published by the Central Government, were used to extract sector energy data for each province during 1997-2009. The datasets include provincial energy use on agriculture, manufacturing, commercial industry and residential consumptions. The energy use data from certain industrial sectors were extracted from CECY, which contains energy consumption data from 39 industrial sectors in 2008. In our study energy used for power generation and heating supply are reallocated into thermal power and heating supply sectors based on the Energy Balance Sheet, thus emissions from electricity and heating have been removed to avoid double counting. We further merged similar industrial sectors in order to match the classification of total output from Chinese Statistics Yearbook. The final sectoral energy data contains 28 sectors in 2008 and 5 groups (Agriculture, Manufacturing, Construction, Commercial Industry and Transportation) during 1997-2009. The sectoral classification is listed in Table 2. By referring the estimation method proposed by Peters et al. [30], the "bottom-up" inventory has been updated for the year of 2009 by using the growth rate of added industrial value. The provincial added industrial value data and GDP data were extracted from Chinese Industrial Economy Yearbook [31] and Chinese Statistics Yearbook [32], respectively. In order to keep consistence, all the GDP data were converted into comparable prices (constant with the value of RMB in 2009), and per capita GDP data were based upon the year-end population of 2009.

GHG emissions (tons $\mathrm{CO}_{2} \mathrm{eq}$ ) from 30 provinces (including Beijing, Tianjin, Shanghai and Chongqing, which are four municipal cities politically equal to one province) were calculated based on 2006 IPCC Guidelines for National Green house Gas Inventories [33]. A detailed inventory covering GHG emission from 28 sectors for the year of 2009 was constructed in order to analyze the distribution and disparity of GHG emission among different regions and sectors.15 types of fuels were considered for driving energy consumption in each sector. Table 3 lists GHG emission factors (EF) for different fuels. Total GHG emissions were derived from direct $\mathrm{CO}_{2}, \mathrm{~N}_{2} \mathrm{O}$ and $\mathrm{CH}_{4}$ emissions. The full accounting approach can be referred by Peters et al. [28] and Fridley [29].

\subsection{Selection of research methods}

Two kinds of quantitative methods were employed in this study: coefficient of variation (CV) analysis for disparity assessment, and logarithmic mean divisa index (LMDI) method for decomposition analysis. CV analysis is an easy but effective way to assess the disparity among variables and has been widely used among various disciplines [34,35]. Index decomposition analysis (IDA) is a classic method on quantifying the contribution of various dimensions for shaping the trajectories of energy consumption and GHG emission, due to its adaptability and simplicity [36-39]. Among various index decomposition analysis methods, the logarithmic mean divisa index (LMDI) method has its own advantages over other
Table 2

Sectoral classification for GHG emission inventories.

\begin{tabular}{|c|c|c|}
\hline $\begin{array}{l}\text { Level } 1 \\
\text { (available 1997-2009) }\end{array}$ & $\begin{array}{l}\text { Level } 2 \\
\text { (available 2009) }\end{array}$ & Level 3 (available 2009) \\
\hline Agriculture & Agriculture & 1.Agriculture \\
\hline \multirow[t]{11}{*}{ Manufacturing } & Mining & $\begin{array}{l}\text { 2.Coal Mining and Dressing } \\
\text { 3.Petroleum and Natural } \\
\text { Gas Extraction } \\
\text { 4.Metals mining } \\
\text { 5.Nonmetal mining }\end{array}$ \\
\hline & Food Production & 6.Food, drinks and tobacco \\
\hline & Textile, Paper and & 7.Textile Industry \\
\hline & Wood Industry & $\begin{array}{l}\text { 8.Wearing } \\
\text { 9.Forest industry } \\
\text { 10.Papers }\end{array}$ \\
\hline & $\begin{array}{l}\text { Petroleum and } \\
\text { Chemical Industry }\end{array}$ & $\begin{array}{l}\text { 11.Petroleum Processing } \\
\text { and Coking } \\
\text { 12.Chemicals }\end{array}$ \\
\hline & Nonmetal and & 13.Nonmetal Mineral Products \\
\hline & Metal Production & 14.Metal Products \\
\hline & Smelting & 15.Smelting \\
\hline & Machinery & 16.Machinery \\
\hline & & $\begin{array}{l}\text { 17.Transportation Equipment } \\
\text { 18.Electric Equipment and } \\
\text { Machinery } \\
\text { 19.Electronic and } \\
\text { Telecommunications Equipment } \\
\text { 20.Instruments, Meters, } \\
\text { Cultural and Office Machinery } \\
\text { 21.Other Manufacturing Industry }\end{array}$ \\
\hline & power Generation & $\begin{array}{l}\text { 22.Production and Supply of } \\
\text { Electric Power, Steam and } \\
\text { Hot Water } \\
\text { 23.Production and Supply of Gas } \\
\text { 24.Production and Supply of } \\
\text { Tap Water }\end{array}$ \\
\hline Construction & Construction & 25.Construction \\
\hline Transportation & Transportation & $\begin{array}{l}\text { 26.Transportation, Storage, } \\
\text { Post and Telecommunication } \\
\text { Services }\end{array}$ \\
\hline Commercial Industry & $\begin{array}{l}\text { Commercial } \\
\text { industry } \\
\text { and other services }\end{array}$ & $\begin{array}{l}\text { 27.Wholesale, Retail Trade } \\
\text { and Catering Services } \\
\text { 28.Others }\end{array}$ \\
\hline
\end{tabular}

Table 3

GHG emission factors for various energy types.

\begin{tabular}{|c|c|c|c|c|c|c|}
\hline & $\begin{array}{l}\text { Oxidation } \\
\text { rate }(\%)\end{array}$ & $\begin{array}{l}\text { Net } \\
\text { calorific } \\
\text { value }\left(10^{12}\right. \\
\left.\mathrm{J} / 10^{3} \text { ton }\right)\end{array}$ & $\begin{array}{l}\mathrm{CO}_{2} \\
\text { emission } \\
\text { factor } \\
\text { (ton } \mathrm{CO}_{2} / \\
\left.10^{12} \mathrm{~J}\right)\end{array}$ & $\begin{array}{l}\mathrm{CH}_{4} \\
\text { emission } \\
\text { factor } \\
\text { (ton } / 10^{15} \mathrm{~J} \text { ) }\end{array}$ & $\begin{array}{l}\mathrm{N}_{2} \mathrm{O} \\
\text { emission } \\
\text { factor } \\
\left(\text { ton } / 10^{15} \mathrm{~J}\right)\end{array}$ & $\begin{array}{l}\text { GHG } \\
\text { emission } \\
\text { (ton } \\
\mathrm{CO}_{2} \mathrm{e} / \text { ton) }\end{array}$ \\
\hline Raw Coal & 100 & 20.91 & 94.60 & 1.00 & 1.50 & 1.99 \\
\hline $\begin{array}{c}\text { Cleaned } \\
\text { Coal }\end{array}$ & 100 & 26.34 & 98.30 & 1.00 & 1.50 & 2.60 \\
\hline $\begin{array}{c}\text { Washed } \\
\text { Coal }\end{array}$ & 100 & 8.36 & 97.90 & 1.00 & 1.50 & 0.82 \\
\hline Briquettes & 100 & 26.34 & 97.90 & 1.00 & 1.50 & 2.59 \\
\hline Coke & 100 & 28.44 & 107.07 & 1.00 & 1.50 & 3.06 \\
\hline $\begin{array}{l}\text { Coke } \\
\text { Oven Gas }\end{array}$ & 100 & $17.35^{\mathrm{a}}$ & 44.37 & 1.00 & 0.10 & $7.71^{\mathrm{b}}$ \\
\hline Other Gas & 100 & $17.35^{\mathrm{a}}$ & 44.37 & 1.00 & 0.10 & $7.71^{\mathrm{b}}$ \\
\hline Crude Oil & 100 & 41.82 & 73.33 & 3.00 & 0.60 & 3.08 \\
\hline Gasoline & 100 & 43.07 & 69.30 & 3.00 & 0.60 & 3.00 \\
\hline Kerosene & 100 & 43.07 & 71.87 & 3.00 & 0.60 & 3.11 \\
\hline Diesel & 100 & 42.65 & 74.07 & 3.00 & 0.60 & 3.17 \\
\hline Fuel Oil & 100 & 41.82 & 77.73 & 3.00 & 0.60 & 3.26 \\
\hline LPG & 100 & 50.18 & 63.07 & 1.00 & 0.10 & 3.17 \\
\hline $\begin{array}{c}\text { Refinery } \\
\text { Gas }\end{array}$ & 100 & 46.06 & 66.73 & 1.00 & 0.10 & 3.08 \\
\hline $\begin{array}{c}\text { Natural } \\
\text { Gas }\end{array}$ & 100 & $38.93^{\mathrm{a}}$ & 56.10 & 1.00 & 0.10 & $21.86^{\mathrm{b}}$ \\
\hline
\end{tabular}

Source: NBS [11], IPCC [33]

a The unit is $103 \mathrm{~J} / \mathrm{m}^{3}$.

b The unit is ton- $\mathrm{CO}_{2} \mathrm{e} / 10^{4} \mathrm{~m}^{3}$. 


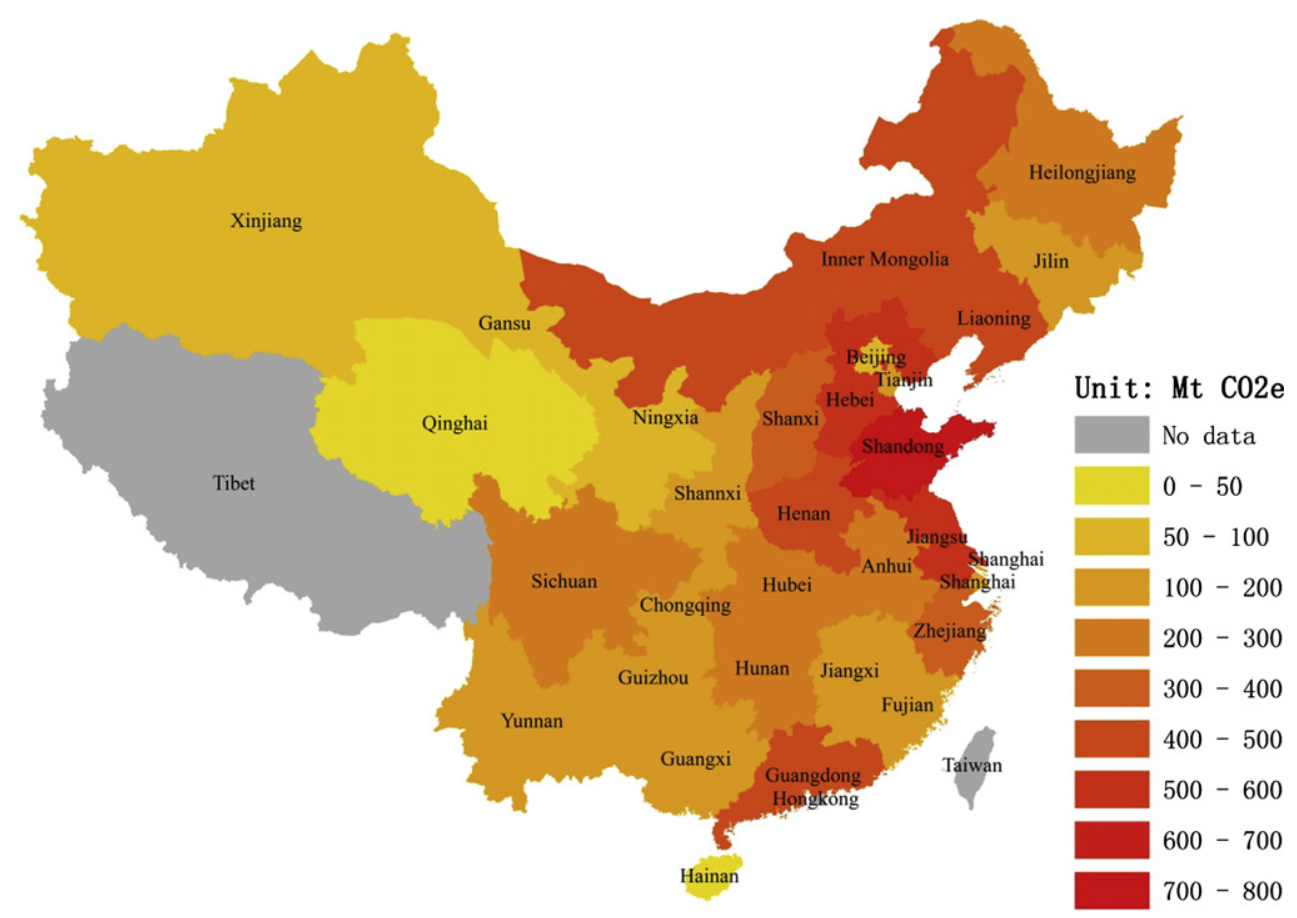

Fig. 1. China's provincial GHG Emission in 2009.

decomposition analysis methods due to its path independency, consistency in aggregation and easily interpreted results [37,39]. Therefore, LMDI method has been selected in this study for analyzing how industrial sectoral emission drove the growth of provincial GHG emissions in China. In addition, the historical change of GHG emissions is decomposed into three driving force factors: overall industrial activity (Activity Effect), activity mix (Structure Effect) and sectoral GHG emission intensity (Intensity Effect). Activity effect describes the contribution of GDP to GHG emission increment, namely, total economic scale. Structure effect is an indicator for evaluating the contribution of industrial structure change on GHG emission increment. Intensity effect refers to the effect of GHG intensity (GHG emissions per unit GDP) on GHG emission increment and is used to evaluate the contribution of technology improvement on GHG emission reduction. Comprehensive description of activity effect, intensity effect and structure effect and the associated calculation were introduced by Ang [40].

\section{Results}

\subsection{Spatial and regional pattern of GHG emission in 2009}

By constructing a "bottom-up" inventory which covers 29 sectors' emission in 2009, the whole landscape of China's provincial emission is uncovered. Fig. 1 presents the spatial pattern of total GHG emission, Fig. 2 depicts a comparison of emission intensity

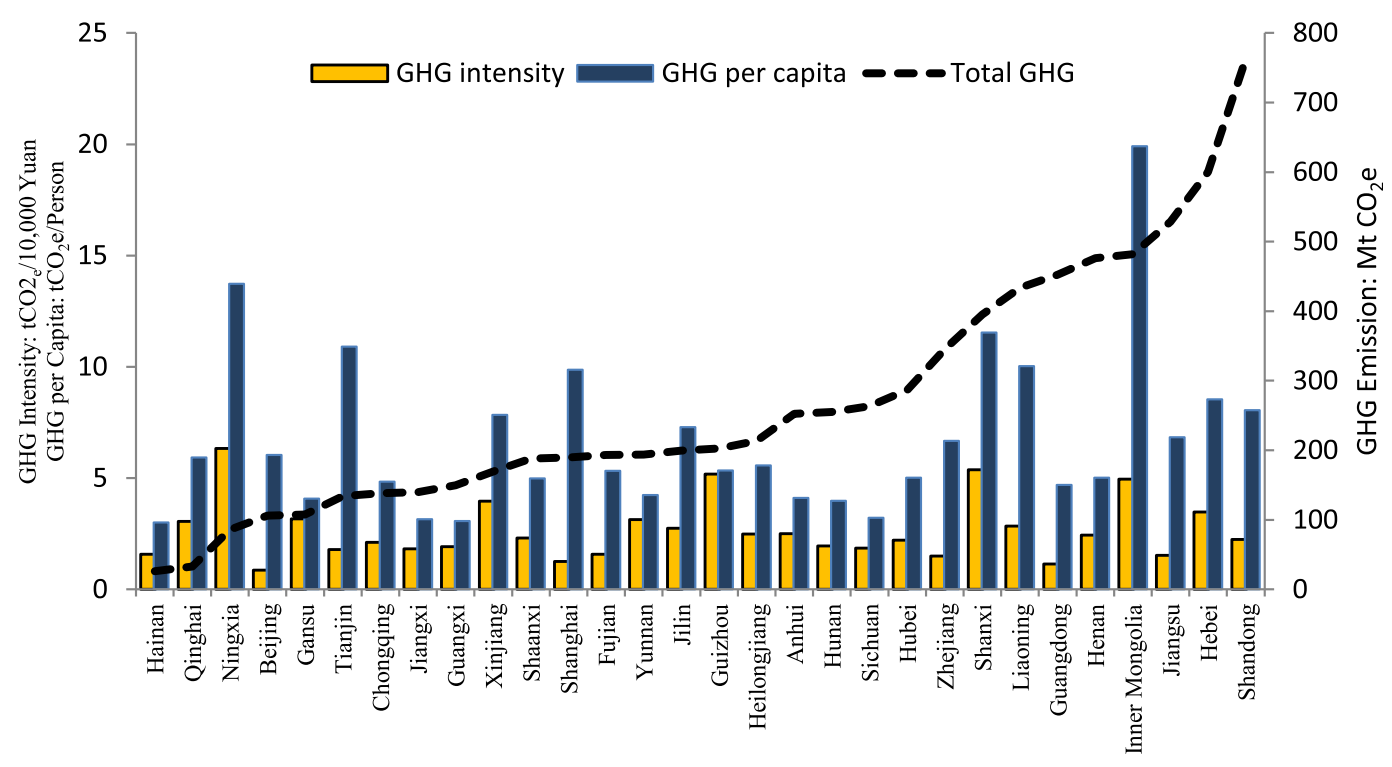

Fig. 2. Comparison of total emission, per capita emission and emission intensity among different provinces. 


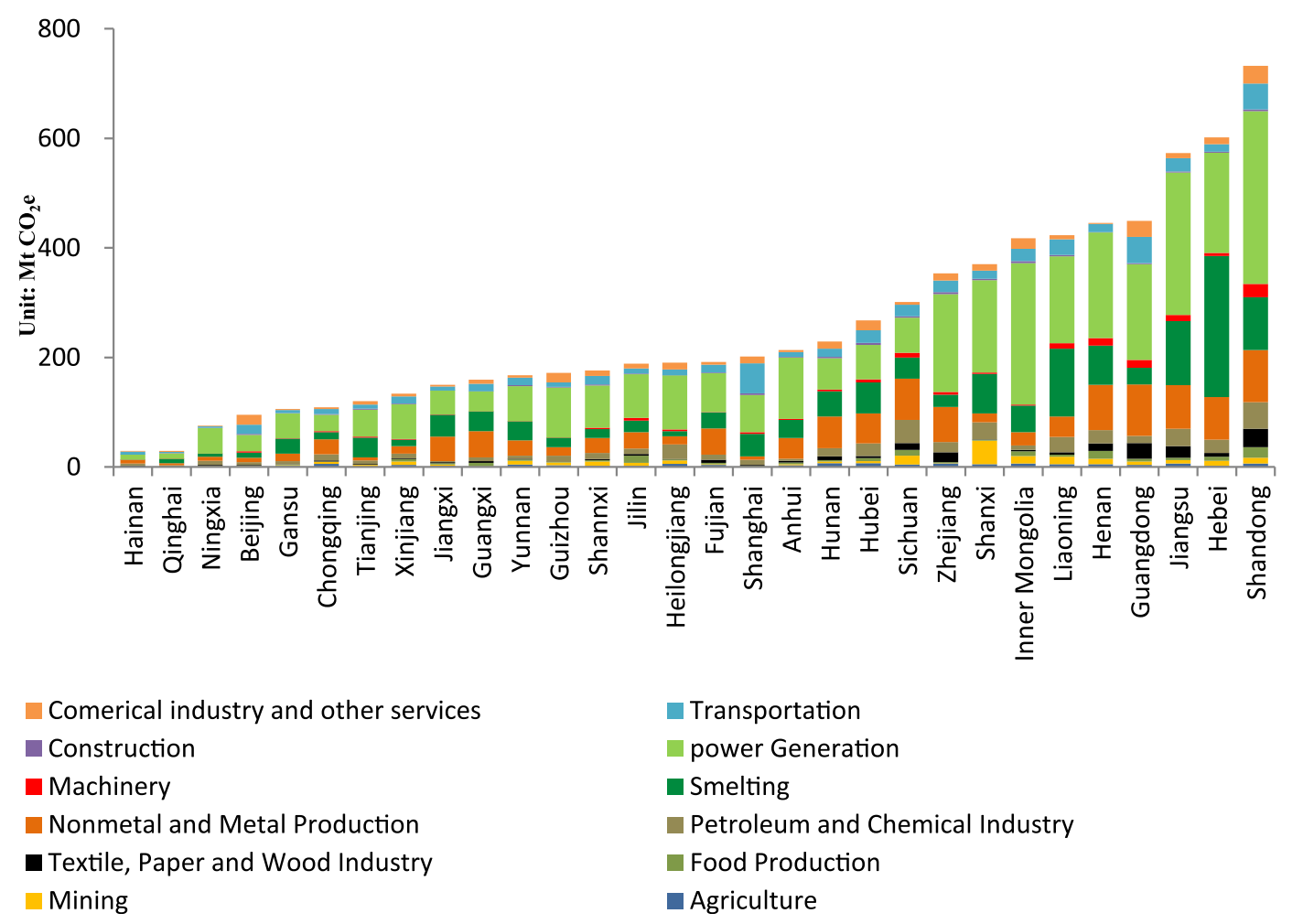

Fig. 3. Sectoral GHG emissions for different provinces in 2009.

Table 4

Sectoral/regional emission intensity.

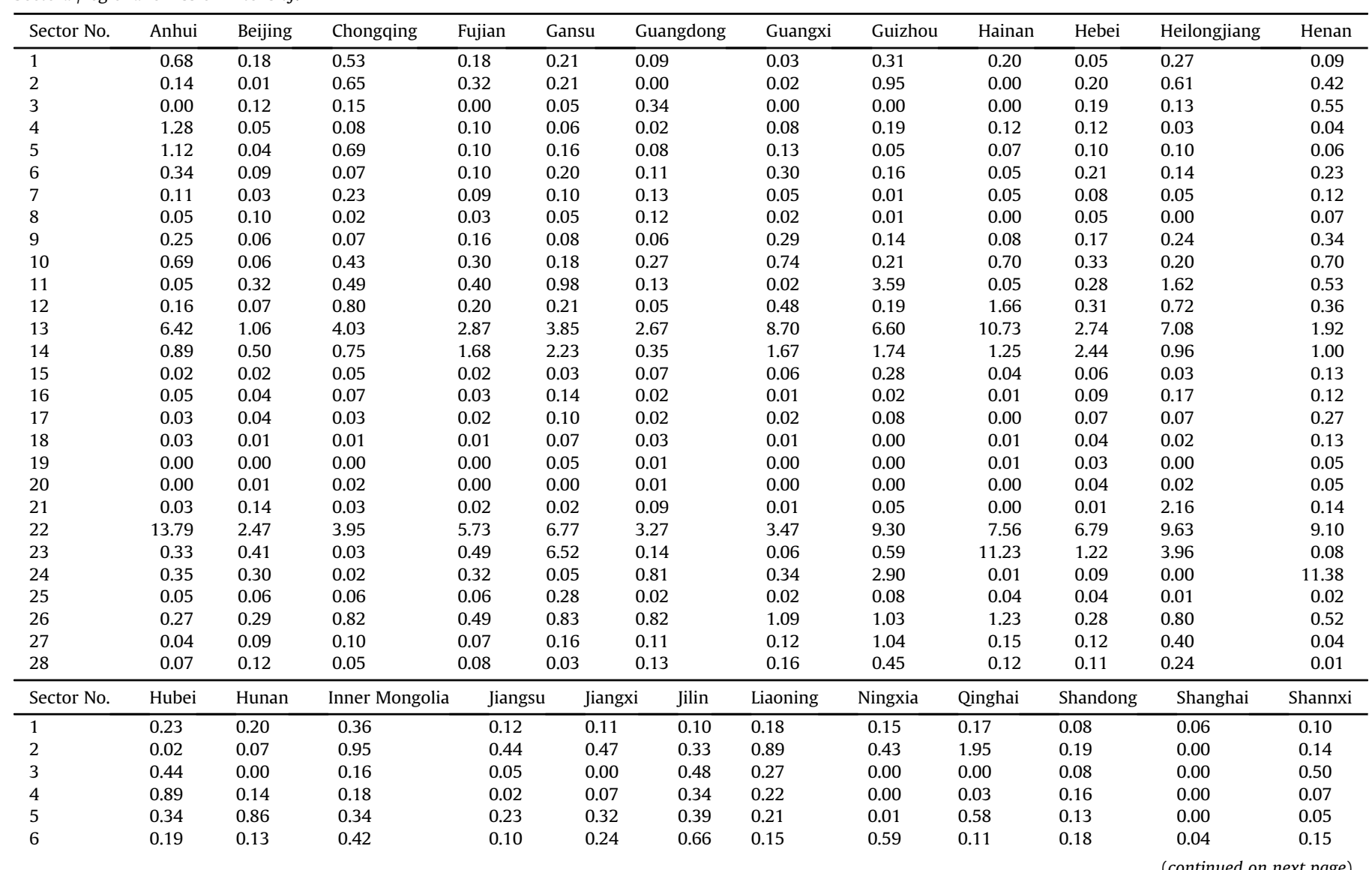


Table 4 (continued)

\begin{tabular}{|c|c|c|c|c|c|c|c|c|c|c|c|c|}
\hline Sector No. & Hubei & Hunan & Inner Mongolia & Jiangsu & Jiangxi & Jilin & Liaoning & Ningxia & Qinghai & Shandong & Shanghai & Shannxi \\
\hline 7 & 0.07 & 0.10 & 0.11 & 0.09 & 0.05 & 0.04 & 0.10 & 0.02 & 0.14 & 0.24 & 0.05 & 0.10 \\
\hline 8 & 0.07 & 0.04 & 0.04 & 0.11 & 0.02 & 0.02 & 0.13 & 0.04 & 0.00 & 0.14 & 0.04 & 0.01 \\
\hline 9 & 0.19 & 0.87 & 0.48 & 0.33 & 0.06 & 2.13 & 0.29 & 0.03 & 0.00 & 0.83 & 0.04 & 0.01 \\
\hline 10 & 0.27 & 0.73 & 0.45 & 0.38 & 0.16 & 0.64 & 0.25 & 2.23 & 0.01 & 0.49 & 0.06 & 0.49 \\
\hline 11 & 0.16 & 0.52 & 0.72 & 0.17 & 0.34 & 0.09 & 0.41 & 1.84 & 0.71 & 0.41 & 0.46 & 0.76 \\
\hline 12 & 1.05 & 0.48 & 0.35 & 0.19 & 0.03 & 0.34 & 0.35 & 1.21 & 0.59 & 0.31 & 0.03 & 0.07 \\
\hline 13 & 4.94 & 5.29 & 3.50 & 2.76 & 7.53 & 5.78 & 2.46 & 8.77 & 4.89 & 2.39 & 0.44 & 3.73 \\
\hline 14 & 3.45 & 1.50 & 1.68 & 0.83 & 1.76 & 1.62 & 2.04 & 1.29 & 1.73 & 1.11 & 0.69 & 0.91 \\
\hline 15 & 0.08 & 0.14 & 0.06 & 0.07 & 0.05 & 0.06 & 0.11 & 0.06 & 0.09 & 0.10 & 0.04 & 0.02 \\
\hline 16 & 0.15 & 0.08 & 0.08 & 0.08 & 0.02 & 0.05 & 0.12 & 0.06 & 0.17 & 0.14 & 0.03 & 0.05 \\
\hline 17 & 0.22 & 0.07 & 0.02 & 0.04 & 0.05 & 0.09 & 0.09 & 0.00 & 0.00 & 0.10 & 0.02 & 0.09 \\
\hline 18 & 0.08 & 0.08 & 0.19 & 0.03 & 0.02 & 0.03 & 0.08 & 0.03 & 0.71 & 0.19 & 0.01 & 0.02 \\
\hline 19 & 0.01 & 0.06 & 0.00 & 0.00 & 0.01 & 0.03 & 0.01 & 0.00 & 0.00 & 0.04 & 0.00 & 0.06 \\
\hline 20 & 0.02 & 0.04 & 0.00 & 0.01 & 0.01 & 0.04 & 0.02 & 0.08 & 0.00 & 0.06 & 0.00 & 0.03 \\
\hline 21 & 0.09 & 0.03 & 0.03 & 0.01 & 0.04 & 0.07 & 0.13 & 0.00 & 0.04 & 0.10 & 0.01 & 0.11 \\
\hline 22 & 7.16 & 5.35 & 21.45 & 7.70 & 3.77 & 7.92 & 9.03 & 14.26 & 5.76 & 8.55 & 4.74 & 10.49 \\
\hline 23 & 0.02 & 0.02 & 0.23 & 5.93 & 0.16 & 0.06 & 0.10 & 1.58 & 0.19 & 0.33 & 0.69 & 0.16 \\
\hline 24 & 0.01 & 0.03 & 4.26 & 1.23 & 0.03 & 0.21 & 1.25 & 0.00 & 0.00 & 3.07 & 0.90 & 0.02 \\
\hline 25 & 0.16 & 0.05 & 0.11 & 0.03 & 0.01 & 0.03 & 0.04 & 0.09 & 0.07 & 0.06 & 0.11 & 0.04 \\
\hline 26 & 1.17 & 0.85 & 1.01 & 0.52 & 0.50 & 0.84 & 1.18 & 1.06 & 1.04 & 0.88 & 0.76 & 1.03 \\
\hline 27 & 0.50 & 0.47 & 0.78 & 0.02 & 0.07 & 0.18 & 0.06 & 0.25 & 0.42 & 0.30 & 0.14 & 0.27 \\
\hline 28 & 0.15 & 0.10 & 0.18 & 0.06 & 0.09 & 0.21 & 0.13 & 0.13 & 0.27 & 0.15 & 0.06 & 0.19 \\
\hline Sector No. & & \multicolumn{2}{|c|}{ Hubei } & \multicolumn{2}{|c|}{ Hunan } & \multicolumn{4}{|c|}{ Inner Mongolia } & \multicolumn{2}{|l|}{ Jiangsu } & Jiangxi \\
\hline 1 & & \multicolumn{2}{|c|}{0.23} & \multicolumn{2}{|c|}{0.20} & \multicolumn{4}{|c|}{0.36} & \multicolumn{2}{|l|}{0.12} & 0.11 \\
\hline 2 & & \multicolumn{2}{|c|}{0.02} & \multicolumn{2}{|l|}{0.07} & \multicolumn{4}{|c|}{0.95} & \multicolumn{2}{|l|}{0.44} & 0.47 \\
\hline 3 & & \multicolumn{2}{|c|}{0.44} & \multicolumn{2}{|l|}{0.00} & \multicolumn{4}{|c|}{0.16} & \multicolumn{2}{|l|}{0.05} & 0.00 \\
\hline 4 & & \multicolumn{2}{|c|}{0.89} & 0.14 & & & 0.18 & & & 0.02 & & 0.07 \\
\hline 5 & & & & 0.86 & & & 0.34 & & & 0.23 & & 0.32 \\
\hline 6 & & & & 0.13 & & & 0.42 & & & 0.10 & & 0.24 \\
\hline 7 & & & & 0.10 & & & 0.11 & & & 0.09 & & 0.05 \\
\hline 8 & & & & 0.04 & & & 0.04 & & & 0.11 & & 0.02 \\
\hline 9 & & & & 0.87 & & & 0.48 & & & 0.33 & & 0.06 \\
\hline 10 & & & & 0.73 & & & 0.45 & & & 0.38 & & 0.16 \\
\hline 11 & & & & 0.52 & & & 0.72 & & & 0.17 & & 0.34 \\
\hline 12 & & & & 0.48 & & & 0.35 & & & 0.19 & & 0.03 \\
\hline 13 & & & & 5.29 & & & 3.50 & & & 2.76 & & 7.53 \\
\hline 14 & & & & 1.50 & & & 1.68 & & & 0.83 & & 1.76 \\
\hline 15 & & & & 0.14 & & & 0.06 & & & 0.07 & & 0.05 \\
\hline 16 & & & & 0.08 & & & 0.08 & & & 0.08 & & 0.02 \\
\hline 17 & & & & 0.07 & & & 0.02 & & & 0.04 & & 0.05 \\
\hline 18 & & & & 0.08 & & & 0.19 & & & 0.03 & & 0.02 \\
\hline 19 & & & & 0.06 & & & 0.00 & & & 0.00 & & 0.01 \\
\hline 20 & & & & 0.04 & & & 0.00 & & & 0.01 & & 0.01 \\
\hline 21 & & & & 0.03 & & & 0.03 & & & 0.01 & & 0.04 \\
\hline 22 & & & & 5.35 & & & 21.45 & & & 7.70 & & 3.77 \\
\hline 23 & & & & 0.02 & & & 0.23 & & & 5.93 & & 0.16 \\
\hline 24 & & & & 0.03 & & & 4.26 & & & 1.23 & & 0.03 \\
\hline 25 & & & & 0.05 & & & 0.11 & & & 0.03 & & 0.01 \\
\hline 26 & & & & 0.85 & & & 1.01 & & & 0.52 & & 0.50 \\
\hline 27 & & & & 0.47 & & & 0.78 & & & 0.02 & & 0.07 \\
\hline 28 & & & & 0.10 & & & 0.18 & & & 0.06 & & 0.09 \\
\hline
\end{tabular}

Unit: $\mathrm{tCO}_{2} / 10000$ Yuan.

Sectoral classification: see Table 2.

and per capita emission, and Fig. 3 illustrates the sectoral information on GHG emission from each province.

Apparently a huge disparity exists among the provincial distribution of total emission, emission intensity and per capita emission. Developed eastern coastal regions (such as Guangdong, Zhejiang and Jiangsu) have both higher total emissions and per capita emissions, but with relatively lower emission intensity.
Those Mid-levelled regions (such as Hebei, Inner Mongolia and Shanxi) have both higher total emissions and emission intensity because their economic activities are dominated by intensive resource mining (primary energy) and other heavy industries. Those least developed western regions (such as Qinghai and Ningxia) have lower total GHG emissions, but higher per capita emissions and emission intensity.

Table 5

Disparity of provincial per capita emission during 1997-2009.

\begin{tabular}{|c|c|c|c|c|c|c|c|c|c|c|c|c|c|}
\hline Year & 1997 & 1998 & 1999 & 2000 & 2001 & 2002 & 2003 & 2004 & 2005 & 2006 & 2007 & 2008 & 2009 \\
\hline Standard Deviation & 1.66 & 1.62 & 1.73 & 1.72 & 1.68 & 2.06 & 2.21 & 2.32 & 2.50 & 2.68 & 3.08 & 3.49 & 3.68 \\
\hline Average per capita emission ( $\left.\mathrm{CO}^{2} / \mathrm{cap}\right)$ & 3.00 & 3.04 & 3.01 & 3.06 & 3.13 & 3.51 & 3.88 & 4.33 & 4.99 & 5.48 & 6.06 & 6.43 & 6.76 \\
\hline $\mathrm{CV}(\%)$ & 55 & 53 & 57 & 56 & 54 & 59 & 57 & 54 & 50 & 49 & 51 & 54 & 54 \\
\hline
\end{tabular}


Table 6

Disparity of provincial sectoral emission intensity in 2009.

\begin{tabular}{|c|c|c|c|}
\hline & $\begin{array}{l}\text { Standard } \\
\text { deviation }\end{array}$ & $\begin{array}{l}\text { Average } \\
\text { intensity } \\
\left(\mathrm{tCO}_{2} \mathrm{e} / 10^{4} \mathrm{rmb}\right)\end{array}$ & CV (\%) \\
\hline Agriculture & 0.22 & 0.23 & 93.74 \\
\hline Coal Mining and Dressing & 0.70 & 0.56 & 125.63 \\
\hline $\begin{array}{l}\text { Petroleum and } \\
\text { Natural Gas Extraction }\end{array}$ & 0.22 & 0.16 & 136.77 \\
\hline Medals mining & 0.28 & 0.20 & 144.19 \\
\hline Nonmetal mining & 0.36 & 0.33 & 110.19 \\
\hline Food, drinks and tobacco & 0.32 & 0.27 & 115.85 \\
\hline Textile Industry & 0.11 & 0.11 & 94.11 \\
\hline Wearing & 0.04 & 0.05 & 84.53 \\
\hline Forest industry & 0.41 & 0.28 & 144.19 \\
\hline Papers & 0.42 & 0.48 & 89.34 \\
\hline $\begin{array}{l}\text { Petroleum Processing } \\
\text { and Coking }\end{array}$ & 0.94 & 0.77 & 121.95 \\
\hline Chemicals & 0.39 & 0.39 & 99.71 \\
\hline Nonmetal Mineral Products & 2.78 & 4.79 & 58.07 \\
\hline Smelting & 0.71 & 1.41 & 50.05 \\
\hline Metal Products & 0.05 & 0.07 & 76.22 \\
\hline Machinery & 0.05 & 0.08 & 71.26 \\
\hline Transportation Equipment & 0.07 & 0.07 & 106.60 \\
\hline $\begin{array}{l}\text { Electric Equipment } \\
\text { and Machinery }\end{array}$ & 0.13 & 0.07 & 197.08 \\
\hline $\begin{array}{l}\text { Electronic and Telecommunications } \\
\text { Equipment }\end{array}$ & 0.14 & 0.04 & 335.27 \\
\hline $\begin{array}{l}\text { Instruments, Meters, Cultural } \\
\text { and Office Machinery }\end{array}$ & 0.02 & 0.02 & 114.43 \\
\hline Other Manufacturing Industry & 0.39 & 0.13 & 306.52 \\
\hline $\begin{array}{l}\text { Production and Supply of Electric } \\
\text { Power, Steam and Hot Water }\end{array}$ & 4.93 & 8.44 & 58.44 \\
\hline Production and Supply of Gas & 2.51 & 1.34 & 187.68 \\
\hline Production and Supply of Tap Water & 2.23 & 1.04 & 213.42 \\
\hline Construction & 0.05 & 0.07 & 79.30 \\
\hline $\begin{array}{l}\text { Transportation, Storage, Post } \\
\text { and Telecommunication Services }\end{array}$ & 0.34 & 0.84 & 40.63 \\
\hline $\begin{array}{l}\text { Wholesale, Retail Trade } \\
\text { and Catering Services }\end{array}$ & 0.25 & 0.24 & 101.63 \\
\hline Others & 0.16 & 0.15 & 103.85 \\
\hline
\end{tabular}

By merging 28 sectors into 12 sectors, results show that "nonmetal and metal production", "smelting and machinery" and "power generation" sectors are three main contributors for total GHG emission. Particularly, provinces having more industrial clusters (such as Shandong and Hebei) have higher proportion of GHG emission from manufacturing related sectors, especially from the sector of "non-metal and metal production" and sector of "smelting". Both Shanxi and Inner Mongolia are energy resource rich areas (especially coal) and have provided a large amount of electricity to their neighboring provinces, thus having higher proportions of GHG emission from power generation sector.

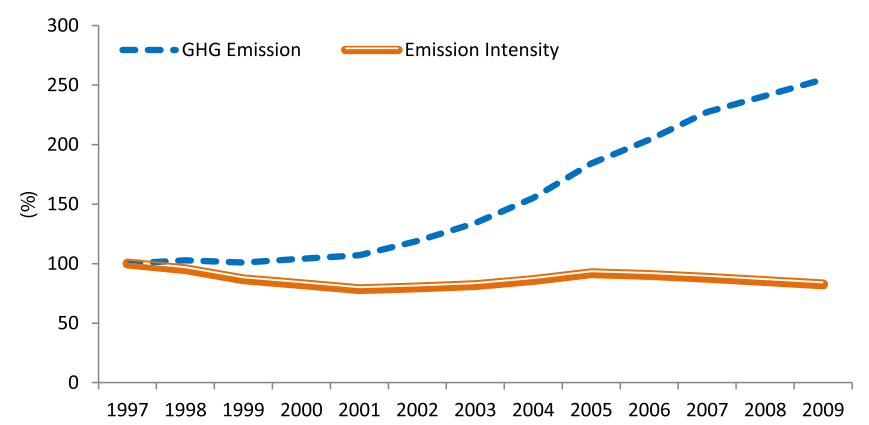

Fig. 4. GHG emission and emission intensity changes during 1997-2009 (1997 as the baseline year).
More importantly, emission intensities in different provinces illustrated significant disparity of technology level among different regions (Table 4). The emission intensities in less developed regions are much higher than those in more developed regions, especially for those with more heavy industries. For example, emission intensity of Chemistry (No.12) production in Hainan is more than twenty times higher than that of in Beijing. Another case in Inner Mongolia, one of China's most productive provinces for energy supply, shows that the emission intensity for its electricity generation is about six times of that in Jiangxi province and five times of that in Shanghai. Similar patterns can also be seen in other sectors, namely, less developed provinces generally have much higher emission intensity for the industrial sectors.

$\mathrm{CV}$ index has been adopted to quantify such technology level disparity. Differences of provincial per capita emission (Table 5) and that of emission intensity for 28 sectors (Table 6 ) are presented. It is clear that on average provincial per capita GHG emissions had been slightly increased during 1997-2009 (Table 5), while the coefficients of variance $(\mathrm{CV})$ on per capita emissions had kept constant during the same period with an average value of about $55 \%$. However, provincial sectoral emission intensity expressed a significant variation (Table 6), with a scale between $40 \%$ (transportation sector) and 335\% (electronic and telecommunications equipment sector) for the year of 2009. Such a huge disparity among different sectors indicates the significant differences of regional technology level.

\subsection{Driving forces for the increment of GHG emissions in 30 provinces during 1997-2009}

The total GHG emissions had been remained relatively constant during 1997-2001, sharply increased during 2002-2005 and slowed down during 2006-2009 (Fig. 4). Such a phase change trend can also be seen in historical change of carbon emission intensity. In order to find reasons for such changes, LMDI was applied for the three periods of 1997-2001, 2002-2005 and 2006-2009, respectively.

Fig. 5 depicts the historic change of GHG emissions with a contribution by different drivers for 30 provinces during 1997-2009. Impacts from three driving forces, namely "activity effect" (Eact), "structure effect" (Estr) and "intensity effect" (Eint) are presented, and more specific results are illustrated in Fig. 6 (for the period of 1997-2001), Fig. 7 (for the period of 2002-2005) and Fig. 8 (for the period of 2006-2009).

These figures show that economic activity effect was the main driver of GHG emissions among all 30 provinces during 1997-2009. Carbon intensity reduction partially offset the increment of GHG emission while economic structure effect contributed to the increase of total GHG emission over the same period. Specifically, significant increase of total GHG emissions existed for the period of 2001-2005, and in most regions both intensity and structure apparently became more carbon intensive for the same period. In 2005-2009, the economic activity was still dramatically increased, but efficiency improvement (presented as intensity decrease) remarkably offset the contribution of economic activity effect. However, economic structure showed a more carbon intensive trend in most regions, especially in less developed provinces.

\section{Discussion and policy implications}

Our research results indicate the significant disparity on GHG emissions between different Chinese provinces, and such disparity is more remarkable in certain industrial sectors. While regional inequity of per capita emission are well recognized and aroused pressing concern recently [22], the technology inequities among different regions have been rarely reported. More importantly, such 


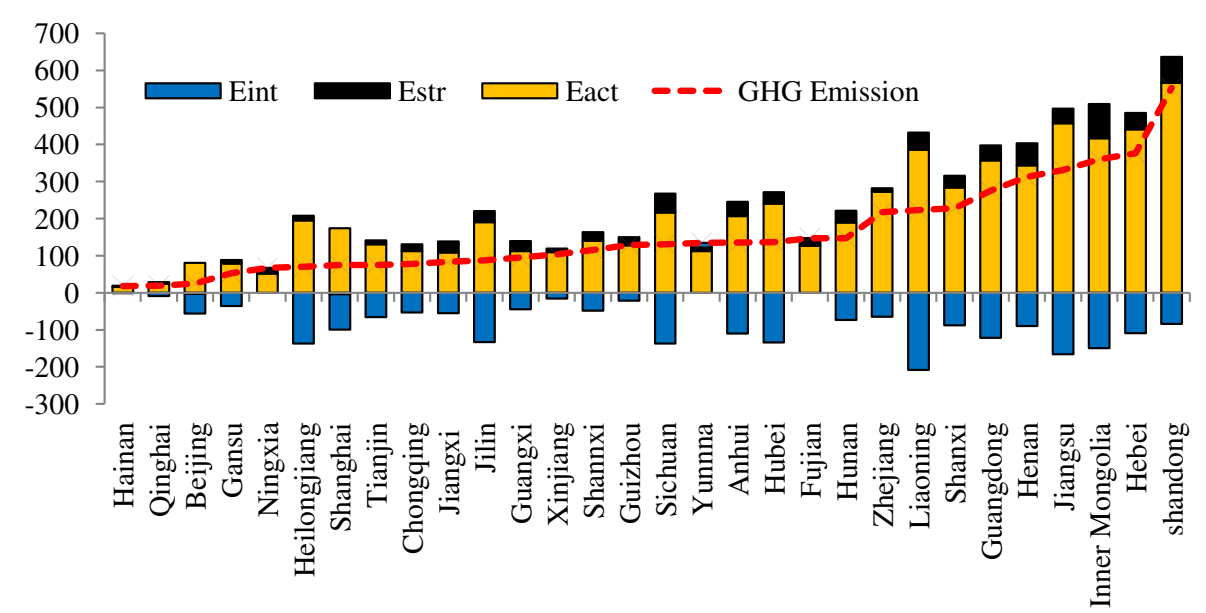

Fig. 5. Driving forces for GHG emission in 30 provinces during 1997-2009 (unit: million tons of CO2e).

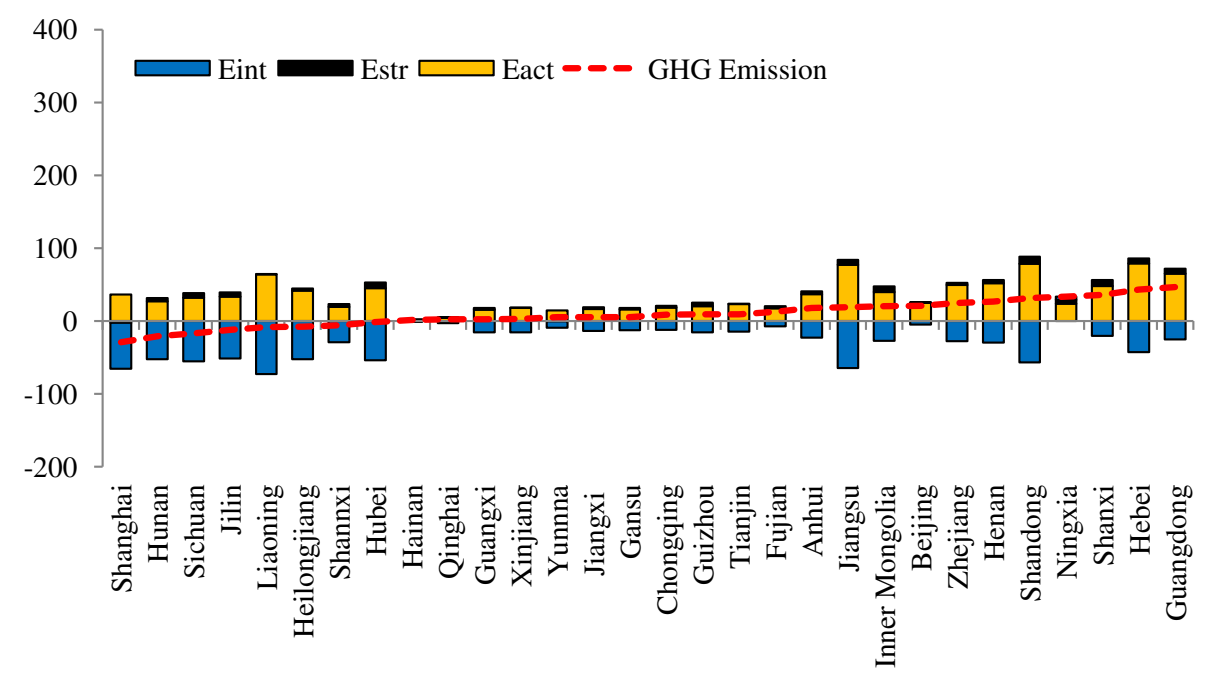

Fig. 6. Driving forces for GHG emission in 30 provinces during 1997-2001 (unit: million tons of CO2e).

technology inequity has a direct connection with China's soaring GHG growth during the period of 1997-2009, and intensity increase in less developed regions had played an important role in total emission increase.
The LMDI analysis revealed that most of GHG increase had been concentrated in those less developed regions since 2001. These poor areas had to struggle for rapid economic growth through supporting energy intensive industry and applying inefficient

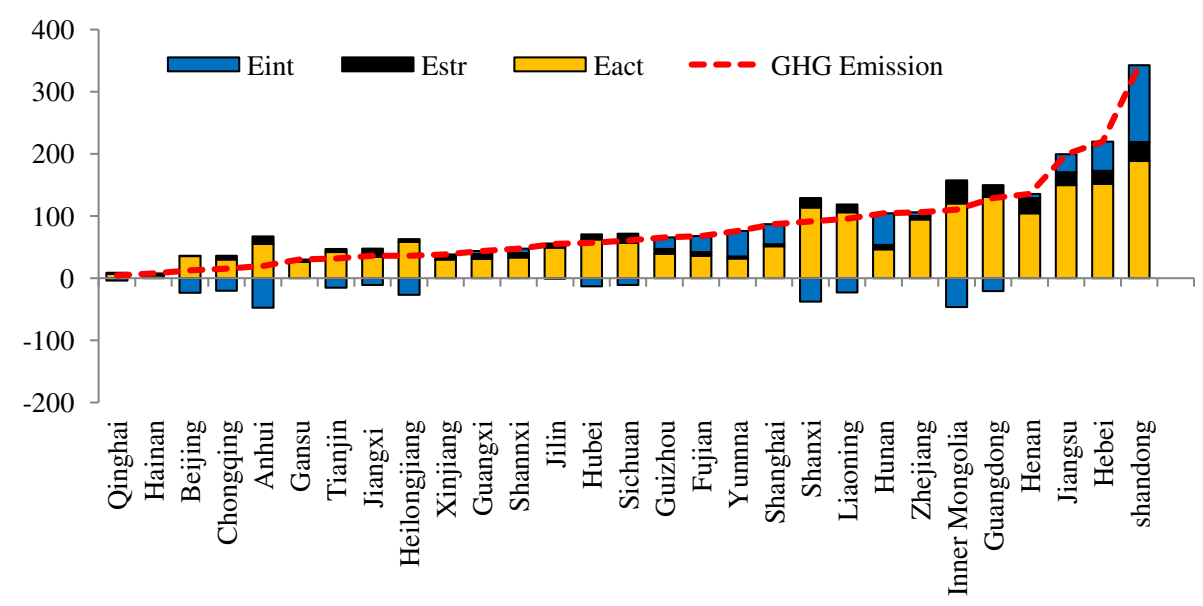

Fig. 7. Driving forces for GHG emission in 30 provinces during 2002-2005 (unit: million tons of CO2e). 


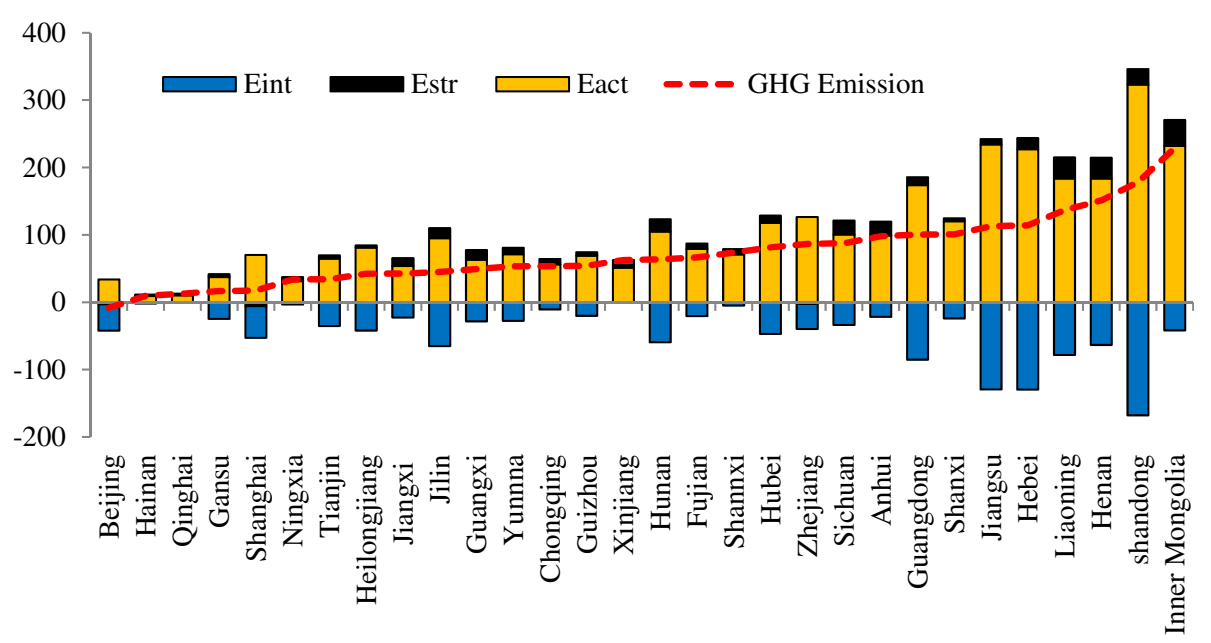

Fig. 8. Driving forces for GHG emission in 30 provinces during 2006-2009 (unit: million tons of CO2e).

technologies (Figs. 4-6). Several provinces, such as Inner Mongolia, Ningxia and Shanxi, have both higher per capita GHG emissions and higher emission intensities, indicating lower energy efficiency and carbon intensive economic structure. In fact, China's overall economy is largely dependent on primary energy resources and these resources are mainly located in less developed regions. Our research illustrates that the efficiency in certain sectors are extremely low in those less developed regions. Beside the economic barrier, technology barrier has become a new challenge for these regions towards sustainable development.

Technology inequity has a direct effect on China's mitigation actions. On one hand the disparity of technology level has not been fully recognized by policy makers, such difference raises a request to revise current energy intensity reduction targets for different provinces. For example, both Beijing municipality (politically equal to a province) and Liaoning province were ranked as "second level" regions, and thus being set with second highest and equivalent emission reduction targets (17\% energy intensity reduction target) (See Table 1). While Beijing is a capital city with more service industries and relying on electricity supply from other provinces [24], Liaoning province is a traditional heavy industrial province with many state-owned manufacturing enterprises and thus cannot change both its industrial structure and energy structure easily. Under such a circumstance, it may be considered by some as unfair to allocate the same emission reduction targets to these two provinces. It may result in that some provincial official take the emissions reduction goals less serious. On the other hand, due to lack of advanced technology and equipment, less developed regions have to employ low-efficient technologies and support energy intensive industries, resulting in carbon intensive economic structure and lower overall eco-efficiency. Unless significant efforts can be made by the central governments to balance technology development, such a trend will continue and make the national emission reduction targets unrealized.

Currently, China's GHG mitigation policies mainly depend on mandatory control of intensity reduction. For example, the dramatic decrease of GHG intensity since 2005 can be explained by the effect of national energy saving and emission reduction policies in its 11th Five-Year Plan (2006-2010). Such a policy targets energy consumption reduction per unit GDP by $20 \%$ and main pollutants reduction ( $\mathrm{COD}$ and $\mathrm{SO}_{2}$ ) per unit GDP by $10 \%$ [41], but there is no mandatory indicator for quantitative control on national and regional economic structure change. Our results illustrate that intensity reduction can contribute to significant offset of total GHG increase, especially after 2005 . However, most attention has been addressed on efficiency improvement, but little is known about China's economic structure which actually has become more carbon intensive due to rapid development of heavy industries. Therefore, a lack of holistic understanding on China's overall development may block the successful implementation of national mitigation actions and lead to a long-term emission increase. Consequently, our research findings can help those policy makers reconsider their emission reduction targets on different regions and make appropriate policies to facilitate technology transfer so that those less developed regions can upgrade their technologies and optimize their industrial structure.

\section{Conclusions}

China's unprecedented industrialization and urbanization has become remarkable during the 21 st century. Such a rapid development brings a great challenge to the whole world both from climate change and resource use points of view. Due to its imbalanced development nature, it is rational to conduct a more detailed study on China's GHG emission so that the real drivers can be found out and appropriate GHG emission reduction policies can be made. Uncovering these dynamics and mechanisms of the interaction among different drivers is an important step toward understanding the complexity of China's GHG emission. This will in turn inform a more coherent economic and environmental policy system that reflects the true dynamics of China's development.

In this study both spatial and sectoral features of China's GHG emissions in 30 provinces were explored. Such a bottom-up investigation can be used to test the applicability of national policies made through a top-down approach. By undertaking both index decomposition analysis and LMDI analysis, our research findings quantitatively explained how economic activities, energy intensity and economic structure contributed the GHG emission increment during 1997-2009. More interestingly, our research outcomes coincided with all the major events during that period, indicating that economic and energy policies do have a strong impacts on GHG emissions and therefore should be carefully enacted by considering the local realities. Also, our research findings presented a holistic picture of China's GHG emission, including its spatial distribution, sectoral emissions, historical evolution, and drivers. Such results can facilitate decision-makers to reconsider their current energy saving and emission reduction targets and revise their related policies. An integrated effort that considers 
resource endowment, historical contribution, economic scale, economic/energy structure, economic instruments and crossregion coordination should be made so that a more balanced, flexible and holistic policy mechanism can be established. Such a mechanism can ensure that the whole country is moving towards low carbon development and actively respond climate change.

\section{Acknowledgments}

This study was supported by Natural Science Foundation of China (71033004, 31100346), Chinese Academy of Sciences (2008318), the Shenyang Scientific Research Foundation (F10-238-6-00), and Ministry of Science and technology (2011BAJ06B01).

\section{References}

[1] U.S. Energy Information Administration (EIA). International energy outlook 2010; 2010.

[2] British Petroleum (BP). BP statistical review of world energy 2011; 2011.

[3] National Development and Reform Commission (NDRC). China's national climate change Programme; 2007. Beijing.

[4] Xinhuanet. The binding index convoy conflict for the energy-saving and emission reduction targets. Xinhuanet, http://news.xinhuanet.com/newsce nter/2007-11/27/content_7155551.htm; 2007.

[5] (NDRC) NDaRC. Mid-long term development plan for renewable energy; 2007. Beijing.

[6] World Wide Fund For Nature (WWF). Strategy and methodology for development of low-carbon city in China; 2011.

[7] Feng K, Hubacek K, Guan D. Lifestyles, technology and $\mathrm{CO}_{2}$ emissions in China: a regional comparative analysis. Ecological Economics 2009;69(1):145-54.

[8] Batisse C, Poncet S. Protectionism and industry location in Chinese provinces. Journal of Chinese Economic and Business Studies 2004;2(2):133-54.

[9] Démurger S. Infrastructure development and economic growth: an explanation for regional disparities in China? Journal of Comparative Economics 2001; 29(1):95-117.

[10] Gregg JS, Andres RJ, Marland G. China: emissions pattern of the world leader in $\mathrm{CO}_{2}$ emissions from fossil fuel consumption and cement production. Geophysical Research Letters 2008;35(8):L08806.

[11] National Bureau of Statistics. China energy statistical yearbook Beijing. China Statistics Press; 1998-2010.

[12] Dechezleprętre A, Glachant M, Méničre Y. Technology transfer by CDM projects: a comparison of Brazil, China, India and Mexico. Energy Policy 2009;37(2):703-11.

[13] Webber CL, Jarmillo P, Marriott J, Samaras C. Life cycle assessment and grid electricity: what do we know and what can we know? Environmental Science \& Technology 2010;44(6):1895-901.

[14] Peters GP, Weber CL, Guan D, Hubacek K. China's growing $\mathrm{CO}_{2}$ emissions. A race between increasing consumption and efficiency gains. Environmental Science \& Technology 2007;41(17):5939-44.

[15] Liang S, Zhang T, Jia X. Clustering economic sectors in China on a life cycle basis to achieve environmental sustainability. Frontiers of Environmental Science \& Engineering 2012. http://dx.doi.org/10.1007/s11783-012-0402-2. online first.

[16] Xu M, Li R, Crittenden JC, Chen Y. $\mathrm{CO}_{2}$ emissions embodied in China's exports from 2002 to 2008: a structural decomposition analysis. Energy Policy 2011; 39(11):7381-8.
[17] Zhang $\mathrm{M}$, Mu H, Ning Y. Accounting for energy-related $\mathrm{CO}_{2}$ emission in China 1991-2006. Energy Policy 2009;37(3):767-73.

[18] Guan D, Hubacek K, Weber CL, Peters GP, Reiner DM. The drivers of Chinese $\mathrm{CO}(2)$ emissions from 1980 to 2030. Global Environmental Change-Human and Policy Dimensions 2008;18(4):626-34.

[19] Liang QM, Fan Y, Wei YM. Multi-regional input-output model for regional energy requirements and $\mathrm{CO}_{2}$ emissions in China. Energy Policy 2007;35(3): 1685-700.

[20] Liu LC, Wang JN, Wu G, Wei YM. China's regional carbon emissions change over 1997-2007. Journal Homepage: www IJEE IEE Foundation Org 2010; 1(1):161-76.

[21] Meng L, Je Guo, Chai J, Zhang Z. China's regional $\mathrm{CO}_{2}$ emissions: characteristics, inter-regional transfer and emission reduction policies. Energy Policy 2011;39(10):6136-44.

[22] Afton Clarke-Sather JQ, Wang Qin, Zeng Jingjing, Yan Li. Carbon inequality at the sub-national scale, a case study of provincial-level inequality in $\mathrm{CO}_{2}$ emissions in China 1997-2007. Energy Policy 2011;39(3):5420-8.

[23] Wei C, Ni J, Du L. Regional allocation of carbon dioxide abatement in China. China Economic Review, in press.

[24] Liu Z, Liang S, Geng Y, Xue B, Xi F, Pan Y, et al. Features, trajectories and driving forces for energy-related GHG emissions from Chinese mega cites: the case of Beijing, Tianjin, Shanghai and Chongqing. Energy 2012;37(1):245-54

[25] Bi J, Zhang R, Wang H, Liu M, Wu Y. The benchmarks of carbon emissions and policy implications for China's cities: case of Nanjing. Energy Policy 2011; 39(9):4785-94.

[26] Xi F, Geng Y, Chen X, Zhang Y, Wang X, Xue B, et al. Contributing to loca policy making on GHG emission reduction through inventorying and attribution: a case study of Shenyang, China. Energy Policy 2011;39(10): 5999-6010.

[27] National Bureau of Statistics. Chinese economic census yearbook 2008; 2011

[28] Peters G, Weber C, Liu J. Construction of chinese energy and emissions inventory. Trondheim: Norwegian University of Science and Technology; 2006.

[29] Fridley D. Inventory of China's energy-related $\mathrm{CO}_{2}$ emissions in 2008. Berkley: Lawrence Berkeley National Laboratory; 2011.

[30] Peters GP, Minx JC, Weber CL, Edenhofer O. Growth in emission transfers via international trade from 1990 to 2008. Proceedings of the National Academy of Sciences 2011;108(21):8903.

[31] National Bureau of Statistics. Chinese industrial economy yearbook 1998-2010.

[32] National Bureau of Statistics. Chinese statistics yearbook; 1998-2010.

[33] Intergovernmental Panel on Climate Change (IPCC). 2006 IPCC Guidelines for national green house gas inventories; 2006

[34] Hendricks WA, Robey KW. The sampling distribution of the coefficient of variation. The Annals of Mathematical Statistics 1936;7(3):129-32.

[35] Lovie P. Coefficient of variation. Encyclopedia of statistics in behavioral science.

[36] Liu FL, Ang BW. Eight methods for decomposing the aggregate energyintensity of industry. Applied Energy 2003;76(1-3):15-23.

[37] Ang BW. Decomposition analysis for policymaking in energy: which is the preferred method? Energy Policy 2004;32(9):1131-9.

[38] Ang BW, Liu FL. A new energy decomposition method: perfect in decomposition and consistent in aggregation. Energy 2001;26(6):537-48.

[39] Ang BW, Zhang FQ. A survey of index decomposition analysis in energy and environmental studies. Energy 2000;25(12):1149-76.

[40] Ang BW. The LMDI approach to decomposition analysis: a practical guide. Energy Policy 2005;33(7):867-71.

[41] Wang Q, Chen Y. Energy saving and emission reduction revolutionizing China's environmental protection. Renewable and Sustainable Energy Reviews 2010;14(1):535-9. 